\title{
Primary myeloid sarcoma of small bowel
}

\author{
Soumya Cicilet, ${ }^{1}$ Francis Krupa Tom, ${ }^{2}$ Babu Philip, ${ }^{2}$ Asthik Biswas ${ }^{2}$
}

Department of Radiodiagnosis, St John's Medical College Hospital, Bangalore, Karnataka, India

${ }^{2}$ Department of Radiology, St John's Medical College Hospital, Bangalore, Karnataka, India

Correspondence to Dr Asthik Biswas, asthikbiswas@gmail.com

Accepted 19 May 2017

\section{CrossMark}

To cite: Cicilet $\mathrm{S}$, Tom FK Philip B, et al. BMJ Case Rep Published Online First: [please include Day Month Year]. doi:10.1136/bcr-2017220503

\section{DESCRIPTION}

A 45-year-old woman presented with severe lower abdominal pain and vomiting. On physical examination, she was found to have tenderness in the suprapubic region and right iliac fossa. An ultrasound abdomen performed to rule out acute appendicitis and pelvic inflammatory disease was not contributory. Blood parameters were within normal limits. As the patient continued to be symptomatic, a contrast-enhanced CT of the abdomen was performed. It revealed eccentric focal bowel wall thickening involving the ileum measuring $3.3 \times 2.4 \mathrm{~cm}$, with homogeneous enhancement on postcontrast images causing mild luminal compromise (figures 1, figure 2). Oral contrast was noted to pass distally with no proximal hold-up. Mild dilatation of proximal ileal loops with diffuse wall thickening was noted (figure 3). No perifocal mesenteric fat infiltration was identified. Few discrete enlarged perifocal lymph nodes were noted (figure 4). There was no retroperitoneal lymphadenopathy. In view of the imaging findings, a differential diagnosis of lymphoma and carcinoma was given.

The patient underwent colonoscopy and biopsy of terminal ileum. However, the scope was not able to reach the aforementioned lesion. The patient underwent laparotomy. Intraoperatively an ulceroproliferative lesion was identified approximately $20 \mathrm{~cm}$ proximal to ileocecal junction. Resection anastomosis of the involved small bowel was performed, and the resected specimen was sent for pathological evaluation. As the neoplastic cells were positive for CD117, LCA, CD34, MPO and Tdt, a diagnosis of myeloid sarcoma was given. There was diffuse wall thickening of the adjacent ileal loops which showed ulceration and inflammatory infiltrates on histopathology. Based on this diagnosis the patient also underwent a bone marrow biopsy to rule out systemic acute myeloid leukaemia, which was found to be within normal limits. The patient was advised chemotherapy.

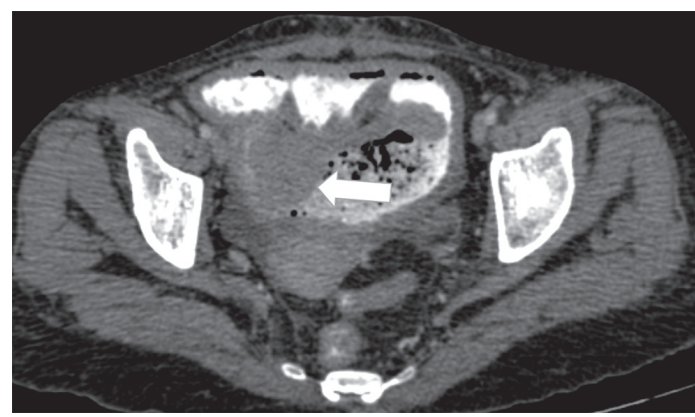

Figure 1 Axial contrast-enhanced CT abdomen showing eccentric focal bowel wall thickening in the ileum protruding into the lumen.
Myeloid sarcoma, otherwise known as granulocytic sarcoma, is a rare extramedullary soft tissue neoplasm composed of primitive cells of myeloid series. ${ }^{1}$ It can occur in any extramedullary location with a higher prevalence in bone and skin. ${ }^{2}$ It can be unifocal or multifocal. Four clinical presentations are expected in myeloid sarcoma: (1) coexisting with acute myeloid leukaemia (AML), (2) harbinger of AML, (3) coexisting with other myelodysplastic syndromes and (4) isolated myeloid sarcoma in a patient with aleukaemia. Myeloid sarcoma is present in only $1 \%-2 \%$ of all patients with AML, and $6.5 \%$ of myeloid sarcomas occur in the gastrointestinal tract. ${ }^{3}$ Isolated myeloid sarcoma of the gastrointestinal tract in a patient with aleukaemia is very rare. This may present with intestinal obstruction or with non-specific complaints of abdominal discomfort and vomiting. ${ }^{4}$ Our patient also presented in a similar manner with clinical suspicion of subacute intestinal obstruction. The most common site of involvement in the gastrointestinal tract is ileum. Myeloid sarcoma has no specific CT imaging feature and hence is indistinguishable from lymphoma, small round cell neoplasms like primitive neuroectodermal tumours or $\mathrm{g}$ on imaging alone. It can manifest as focal bowel wall thickening or polypoidal mass with intraluminal or exophytic components or both. Our case also had similar imaging findings. Literature shows that myeloid sarcoma of the gastrointestinal tract has a high propensity for mesenteric, peritoneal and omental infiltration and perifocal discrete lymphadenopathy. ${ }^{5}$ Except for perifocal lymph nodes, the other features like omental, peritoneal or mesenteric involvement were absent in this case. Complications of this entity are intestinal obstruction, perforation and intussusception. ${ }^{6}$ Chemotherapy and stem cell transplantation are the treatment of choice with or without surgery or radiotherapy. Transformation to

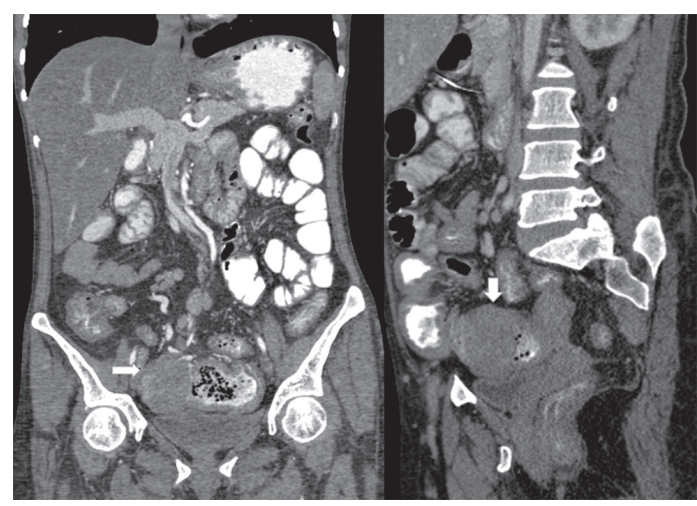

Figure 2 Coronal and oblique sagittal reformatted contrast-enhanced $\mathrm{CT}$ images showing eccentric wall thickening in ileum causing luminal compromise. 


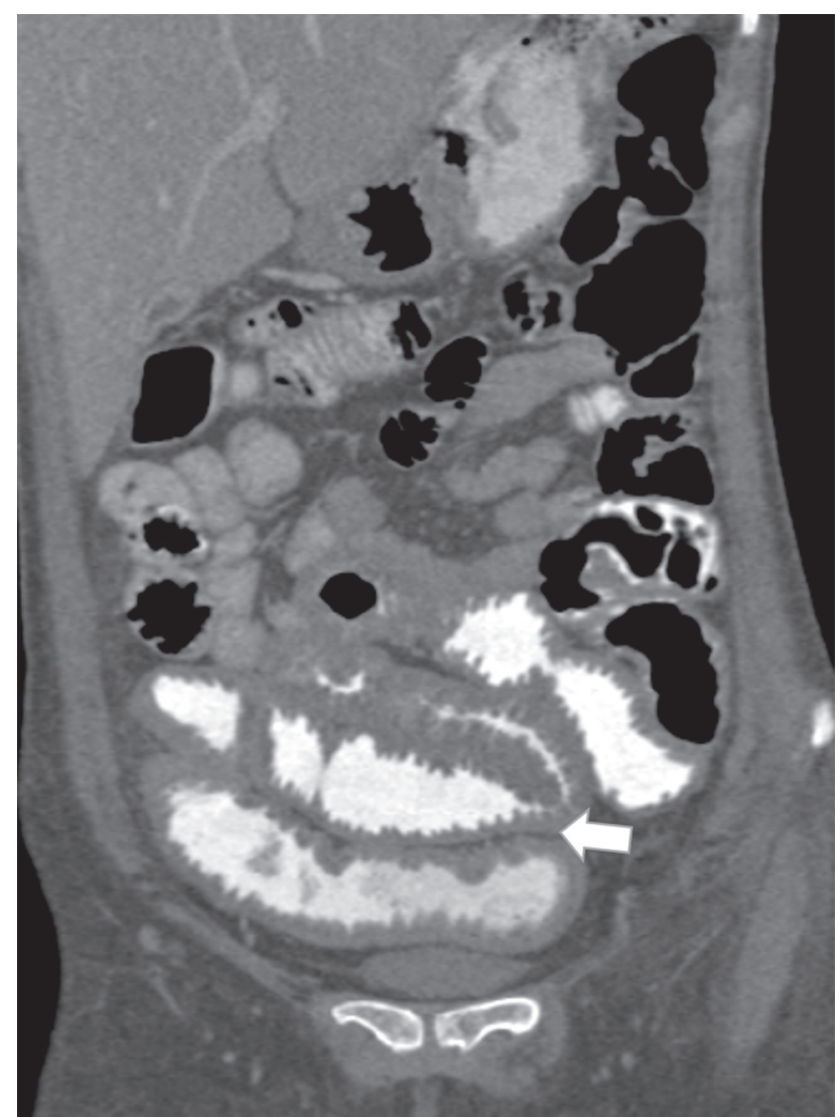

Figure 3 Coronal contrast-enhanced CT abdomen showing mildly dilated ileal loops with circumferential wall thickening.

AML can occur in months without systemic chemotherapy or stem cell transplantation.

Even though immunohistochemistry provides the final diagnosis, imaging helps in localising the site of the pathology, assessing its extent and providing guidance for accurate biopsy.

\section{Learning points}

- Myeloid sarcoma can present in a patient with aleukaemia.

- Gastrointestinal tract is a rare location for myeloid sarcoma.

- Accurate diagnosis of myeloid sarcoma has paramount prognostic implication as transformation to acute myeloid leukaemia can happen without chemotherapy or stem cell transplantation.

Contributors All authors were involved in the conception and design of the paper, participated in writing the manuscript and approved the submitted version. $\mathrm{SC}$ and $\mathrm{AB}$ were involved in planning, conduct, reporting, conception and design. FKT was involved in acquisition of data and interpretation of data. BP reviewed the manuscript and images for final approval.

Competing interests None declared.

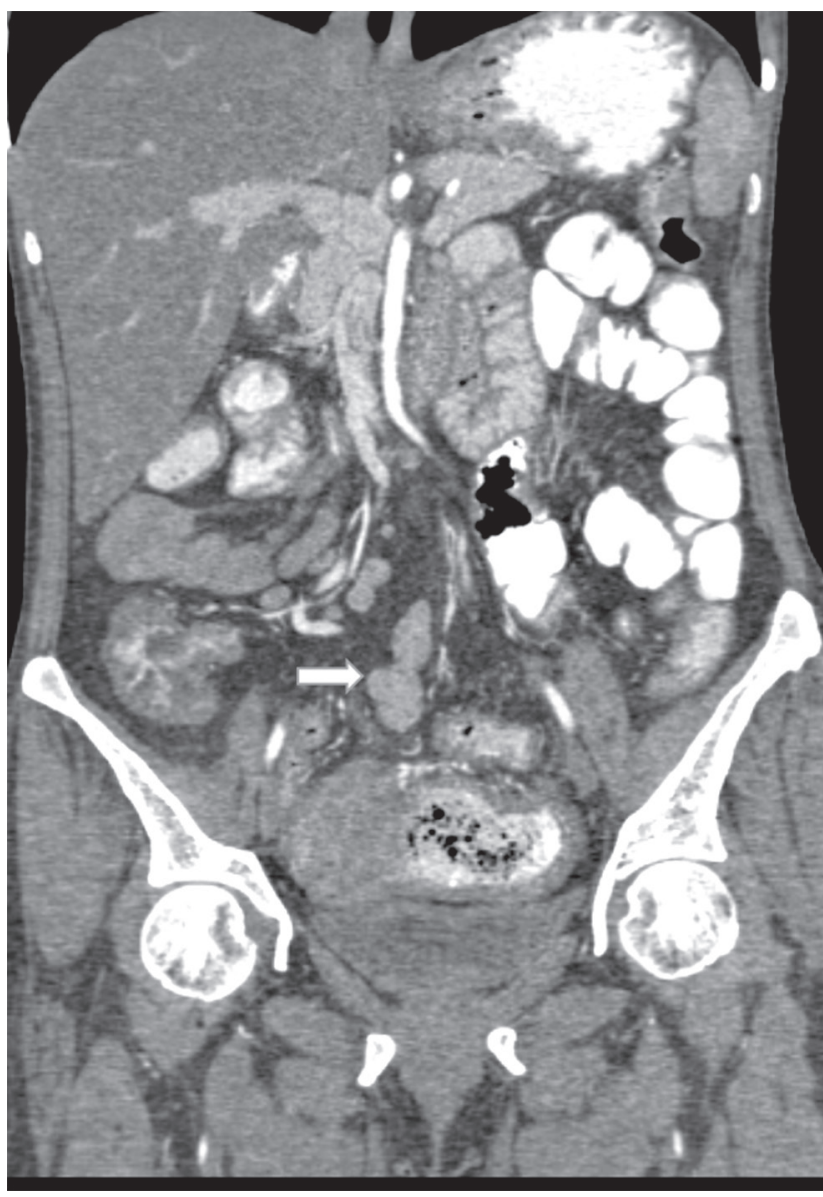

Figure 4 Coronal contrast-enhanced CT image showing discrete enlarged perifocal lymph nodes.

Patient consent Obtained.

Provenance and peer review Not commissioned; externally peer reviewed

(c) BMJ Publishing Group Ltd (unless otherwise stated in the text of the article) 2017. All rights reserved. No commercial use is permitted unless otherwise expressly granted.

\section{REFERENCES}

1 Guermazi A, Feger C, Rousselot P, et al. Granulocytic sarcoma (chloroma): imaging findings in adults and children. AJR Am J Roentgenol 2002;178:319-25.

2 Ooi GC, Chim CS, Khong PL, et al. Radiologic manifestations of granulocytic sarcoma in adult leukemia. AJR Am J Roentgenol 2001;176:1427-31.

$3 \mathrm{Yu} \mathrm{T,} \mathrm{Xu} \mathrm{G,} \mathrm{Xu} \mathrm{X,} \mathrm{et} \mathrm{al.} \mathrm{Myeloid} \mathrm{sarcoma} \mathrm{derived} \mathrm{from} \mathrm{the} \mathrm{gastrointestinal} \mathrm{tract:} \mathrm{a}$ case report and review of the literature. Oncol Lett 2016;11:4155-9.

4 Venizelos ID, Frakandreas G, Tatsiou ZA, et al. Isolated myeloid sarcoma of the small intestine in an aleukemic Patient-Case Report and Review of the Literature. Visc Med 2008:24:171-4.

5 Choi EK, Ha HK, Park SH, et al. Granulocytic sarcoma of bowel: CT findings. Radiology 2007;243:752-.

6 Sevinc A, Buyukberber S, Camci C, et al. Granulocytic sarcoma of the Colon and leukemic infiltration of the liver in a patient presenting with hematochezia and jaundice. Digestion 2004;69:262-5. 
Copyright 2017 BMJ Publishing Group. All rights reserved. For permission to reuse any of this content visit http://group.bmj.com/group/rights-licensing/permissions.

BMJ Case Report Fellows may re-use this article for personal use and teaching without any further permission.

Become a Fellow of BMJ Case Reports today and you can:

- Submit as many cases as you like

- Enjoy fast sympathetic peer review and rapid publication of accepted articles

Access all the published articles

Re-use any of the published material for personal use and teaching without further permission

For information on Institutional Fellowships contact consortiasales@bmjgroup.com

Visit casereports.bmj.com for more articles like this and to become a Fellow 